\title{
„LUDY MORZA” NA TLE PRZEOBRAŻEŃ KULTUROWYCH W STREFIE PONTYJSKO-BAŁKAŃSKIEJ W 2. POŁ. II TYSIĄCLECIA P.N.E.
}

\author{
„THE SEA PEOPLES” AND CULTURAL TRANSFORMATIONS \\ IN THE PONTIC-BALKAN ZONE IN THE SECOND HALF \\ OF THE SECOND MILLENNIUM BC
}

\author{
(autoreferat wygłoszony w trakcie obrony pracy doktorskiej \\ w dniu 22 października 2010 r.)
}

\begin{abstract}
Główny temat moich rozważań w niniejszej dysertacji stanowi sytuacja kulturowa, społeczna i polityczna, jaka w 2. poł. II tysiąclecia p.n.e. panowała na obszarach leżących w zlewniach Morza Czarnego i Morza Egejskiego. Na jej tle zostały ukazane przeobrażenia kulturowe, jakie zaszły w tym czasie w strefie pontyjsko-bałkańskiej. Ramy chronologiczne pracy obejmują lata 1500-1150 p.n.e., czyli okres poprzedzający ekspansję Ludów Morza oraz czas po niej następujący, ze szczególnym uwzględnieniem wydarzeń, jakie rozegrały się na przełomie XIII i XII w. p.n.e.

Podstawowym celem rozprawy było określenie charakteru powiązań pomiędzy wschodnią i południową Europą, które przedstawiono w szerokiej perspektywie przestrzennej obejmującej częściowo środkową Europę, północne Nadczarnomorze, wschodnie Bałkany oraz strefę egejsko-anatolijską. Pozwoliło to na kompleksowy ogląd ówczesnej sytuacji „polityczno-historycznej”. Oś merytoryczna rozważań koncentruje się wokół genezy Ludów Morza, których inwazja na przełomie XIII i XII w. p.n.e. objęła obszary szeroko pojętego wschodniego Śródziemnomorza.
\end{abstract}

\section{DZIEJE BADAŃ NAD LUDAMI MORZA}

W pierwszym rozdziale z różnych, ale uzupełniających się stron została kompleksowo ukazana historia badań nad Ludami Morza. Moim zamiarem było zaprezentowanie głównych kierunków badań nad genezą tego ugrupowania na tle zmieniających się podstaw teoretycznych archeologii. Stąd też rozważania te zostały poprzedzone omówieniem teoretycznych ujęć badań nad etnicznością w pradziejach oraz dziejów studiów nad 
etnicznością $\mathrm{w}$ archeologii. Dopiero na tak zarysowanym gruncie teoretyczno-historycznym zostały szczegółowo przedstawione główne kierunki badań nad genezą Ludów Morza. Główny zrąb tego ujęcia stanowi analiza koncepcji topogenetycznych: egejsko-anatolijskiej, tzw. północnej oraz środkowo- i zachodniośródziemnomorskiej. Zebrane dane pozwalają wnioskować o braku wspólnej genezy najeźdźców. Moim zdaniem grupy Ludów Morza należy traktować jako zbiory heterogeniczne, swojego rodzaju „unię sytuacyjną", zrodzoną na uboczu centrów kulturowych. Co więcej, znane ze źródeł egipskich, ukształtowane już wówczas i relatywnie dobrze rozpoznawane, grupy plemienne nie musiały być tożsame z pierwotnymi jednostkami, od których zaczęła się historia ich kształtowania. Możliwości rozpoznania sekwencji transformacji kulturowych i - zapewne - społecznych, jakie zaszły w trakcie „wędrówki” grup, które złożyły się na Ludy Morza, są jednak bardzo ograniczone.

\section{LUDY MORZA W PERSPEKTYWIE HISTORYCZNEJ (ŹRÓDŁA PISANE I IKONOGRAFICZNE)}

Drugi rozdział dysertacji tworzy wieloaspektowa analiza źródeł pisanych i ikonograficznych, służąca identyfikacji Ludów Morza. Obejmuje ona zestawienie chronologiczne dokumentów egipskich, hetyckich, ugaryckich, hebrajskich, greckich i fenickich oraz charakterystykę obu kategorii źródeł, ze zwróceniem szczegółowej uwagi na zawarte w nich informacje o Ludach Morza. Następnie, na podstawie tych samych dokumentów, została przeprowadzona historyczna identyfikacja plemion konglomeratu, na którą złożyło się sumaryczne zestawienie danych o każdym z ludów. Uwieńczeniem owych zabiegów była próba określenia pochodzenia poszczególnych plemion, która niestety, ze względu na mnogość hipotez, w większości przypadków nie dała możliwości wskazania jednego i w pełni wiarygodnego rozwiązania. Pewien consensus udało się osiągnąć w przypadku Peleset, których powszechnie identyfikuje się z biblijnymi Filistynami. Wskazuje się też na ich możliwe powiązania ze strefą egejską. Kontrowersji nie budzi także lokalizacja ziem Lukka w południowo-zachodniej Azji Mniejszej. Zasadniczą zgodę osiągnięto również w przypadku Tjekker, którzy są uznawani za mieszkańców Troady.

\section{LUDY MORZA W PERSPEKTYWIE ARCHEOLOGICZNEJ: MOŻLIWOŚĆ IDENTYFIKACJI NA PODSTAWIE BLISKOWSCHODNICH ŹRÓDEL MATERIALNYCH}

W rozdziale trzecim zawarto analizę bliskowschodnich źródeł archeologicznych i historycznych odnoszących się do Ludów Morza. Celem było porównanie danych zawartych w obu kategoriach zabytków, zestawienie podobieństw i różnic oraz określe- 
nie, czy się uzupełniają, czy też wykluczają. Dlatego też rozdział podzielono na dwie części: (a) archeologiczną, wiązaną z okresem po inwazji Ludów Morza i (b) historyczną, obejmującą czas bezpośrednich ataków. Ujęcie Ludów Morza w literaturze archeologicznej zostało oparte na analizie pozostałościach architektonicznych (budowle z bloków kamienia, paleniska, pochówki), materiale ceramicznym (naczynia PH IIIC1b, filistyńskie, trojańskie, pitosy) oraz innym materiale ruchomym (m. in. krowie scapulae, ciężarki tkackie, figurki typu Aszdod). Z kolei źródła pisane i ikonograficzne posłużyły do identyfikacji sposobu życia i kultury materialnej Ludów Morza oraz ich samych, co osiągnięto dzięki charakterystyce wyglądu poszczególnych plemion. Zabiegi te pozwoliły przygotować zestaw identyfikatorów plemion Ludów Morza.

Zabytki bliskowschodniej grupy archeologicznej, które w południowo-wschodniej, wybrzeżowej części Morza Śródziemnego pojawiły się w XII w. p.n.e., stanowiły swoiste novum w tym rejonie i łączy się je z przybyciem części plemion Ludów Morza. Na podstawie rozmieszczenia artefaktów możemy przyjąć, iż nowi przybysze dotarli na te tereny z Cypru. Wcześniej prawdopodobnie zamieszkiwali obszar szeroko pojętej strefy egejskiej i odleglejsze rejony środkowej Europy.

Z kolei bliskowschodnie źródła historyczne w przybliżony sposób pozwalają poznać uzbrojenie i dobytek niektórych plemion, ich wygląd oraz sposób prowadzenia walk. Scharakteryzowane zabytki obu grup (archeologicznej i historycznej) tworzą dwa odrębne zbiory taksonomiczne i chronologiczne. Wynikające $\mathrm{z}$ nich informacje są różnej natury i nie uzupełniają się w żaden sposób. Materiały zaliczane do pierwszej grupy to pozostałości po tzw. życiu codziennym, podczas gdy w drugiej znalazły się głównie wszelkiego rodzaju przedmioty wiązane z działalnością militarną. Dlatego też zestawienie i porównanie ich ze sobą nie daje oczekiwanych rezultatów. Można je jedynie analizować oddzielnie, jako dwie niezależne kategorie, które w ograniczony sposób pozwalają poznać pochodzenie poszczególnych plemion Ludów Morza.

\section{PÓŁNOCNA GENEZA LUDÓW MORZA. KONCEPCJE I ICH PODSTAWY ŹRÓDŁOWE}

W kolejnym, czwartym rozdziale z perspektywy archeologicznej przedstawiono wszystkie wersje tzw. północnej genezy Ludów Morza. Jest to główna źródłoznawcza część pracy. Zebrane w niej informacje źródłowe zostały zaczerpnięte $z$ literatury, jak i z autopsji. Wersja środkowoeuropejska. Jej podstawę źródłową stanowi wykaz przedmiotów o środkowoeuropejskiej proweniencji znajdowanych we wschodnim Śródziemnomorzu po 1200 r. p.n.e. Zebrane zabytki można podzielić na trzy grupy: (1) artefakty o środkowoeuropejskiej genezie, (2) zabytki o pochodzeniu głównie północnoitalskim oraz (3) wyroby o korzeniach trudnych do określenia. Do pierwszej grupy zalicza się miecze typu Naue II, groty włóczni, okrągłe tarcze, szpile i motywy zdobnicze w postaci 
ptasich głów. Drugi zbiór tworzą sztylety Peschiera, noże i zapewne zapinki wiolinowe, a trzeci nagolenniki i pancerze. Proweniencja i dystrybucja wyrobów pierwszego i drugiego zbioru, która wiodła zachodnimi Bałkanami do północnej Grecji, następnie na Peloponez, Cyklady, Kretę i dalej na Cypr oraz na Bliski Wschód, przemawia na korzyść przemieszczeń pewnych północnych grup ludzkich do strefy śródziemnomorskiej. Z kolei zabytki trzeciej grupy mogą świadczyć o obopólnych inspiracjach pomiędzy mieszkańcami tych obszarów. W pierwszym przypadku wspomniane społeczności łączy się z Ludami Morza.

Wersja północnopontyjska. Zawiera charakterystykę materiałów o genezie śródziemnomorskiej oraz północnopontyjskiej. Zabytki te można podzielić na trzy grupy: (1) artefakty o północnopontyjskiej proweniencji znane ze wschodniej, ale i centralnej części basenu Morza Śródziemnego, (2) wyroby o wschodniośródziemnomorskim pochodzeniu oraz (3) zabytki o korzeniach centralnoeuropejskich i północnoitalskich, znajdowane nad Morzem Czarnym. Na pierwszą grupę składają się miecze i sztylety typu Krasny Mayak, groty strzał oraz siekierki i toporki. Drugi zbiór tworzą podwójne siekiery i noże, a trzeci miecze typu Naue II, okrągłe tarcze i bursztynowe paciorki. W przypadku tej wersji możemy przyjąć trójstronny przepływ wytworów odbywający się odpowiednio z północy na południe, z południa na północ oraz z zachodu na wschód. Z Ludami Morza łączy się artefakty pierwszego i trzeciego zbioru. Przypuszcza się, że część ugrupowania owych wojowników stanowili członkowie społeczności Sabatinovka, których utożsamia się z ludem Szardana, znanym z przekazów egipskich.

Wersja bałkańska. Jej bazę stanowi analiza zabytków świadczących o wzajemnych kontaktach lub o cyrkulacji wytworów i idei pomiędzy społecznościami bałkańskimi a wschodniośródziemnomorskimi. Zabytki te można podzielić na dwie grupy: (1) artefakty poświadczające przepływ z południa na północ oraz (2) wyroby wskazujące na cyrkulację z północy na południe. Na pierwszy zbiór składają się rapiery i miecze, groty włóczni, podwójne siekiery, ceramika mykeńska, kamienne kotwice, ingoty, sztaby płasko-wypukłe i zabytki piśmiennictwa. Drugą grupę tworzą miecze typu Naue II, miecze i sztylety typu Krasny Mayak, ceremonialne berła i ceramika „barbarzyńska”. Dwustronny obieg wyrobów obu grup przemawia na rzecz długofalowych i długodystansowych relacji pomiędzy mieszkańcami tych obszarów. W kontekście koncepcji północnej genezy Ludów Morza istotne znaczenie mają wyroby drugiego zbioru. Analiza dystrybucji zabytków obu grup pozwala przyjąć następujące kierunki ich przepływu: (1) zachodnimi Bałkanami, do Grecji mykeńskiej, na Kretę, Cypr i na Bliski Wschód oraz (2) wzdłuż Karpat, wschodnimi Bałkanami do wybrzeżowej, zachodniej części Azji Mniejszej. Ważny materiał, zapewnie stanowiący dowód migracji północnych plemion, to ceramika „barbarzyńska”, identyfikowana głównie z materiałem kompleksu kulturowego Sabatinovka-Noua-Coslogeni (S-N-C). Jego obecność na południu kontynentu oraz na Bliskim Wschodzie wydaje się potwierdzać inwazję plemion zaliczanych do Ludów Morza. 


\section{KONCEPCJA PÓŁNOCNEJ GENEZY LUDÓW MORZA NA TLE PRZEOBRAŻEŃ KULTUROWYCH W STREFIE PÓŁNOCNEGO NADCZARNOMORZA, EUROPY ŚRODKOWEJ I BAŁKANÓW W 2. POE. II TYSIĄCLECIA P.N.E.}

Przeobrażenia kulturowe, do jakich doszło w 2. poł. II tysiąclecia p.n.e. w Europie środkowej, północnym Poncie, na Bałkanach, w strefie egejskiej i na Bliskim Wschodzie zostały uchwycone dzięki synchronizacji i charakterystyce kulturowej tych terenów. Jednym z głównych problemów chronologicznych, obok znacznego rozdrobnienia kulturowego, był rozdźwięk między periodyzacjami „śródziemnomorskimi” a „europejskimi”, polegający na stosowaniu dwóch różnych systemów: tradycyjnego (historycznego) oraz nowego (tzw. metody „naukowe”). Ze względu na złożoność kwestii i długoletnią dyskusję toczącą się w literaturze przedmiotu zdecydowałam się pozostać przy periodyzacjach tradycyjnych, jednocześnie sygnalizując możliwość przyszłych zmian. Z kolei charakterystyka kulturowa społeczności środkowoeuropejskich, północnopontyjskich i bałkańskich z jednej strony pozwoliła określić ich wieloraką naturę, a z drugiej wykazała znaczne podobieństwo między wspólnotami nadczarnomorskimi oraz bałkańskimi.

Na podstawie tak ujętej problematyki można było określić różny charakter korelacji kulturowych i więzi społecznych pomiędzy częścią środkową, wschodnią i południową Europy. Ważny w tym względzie okazał się model centrum - peryferii uzupełniony o obszar marginalny, który nie wykazał wzajemnych zależności wymienionych terenów, a jedynie naświetlił przepływ pewnych idei, technologii produkcji, surowców i towarów między nimi. Dlatego też nie należy mówić o dyfuzyjnym charakterze relacji, jakie łączyły te rejony, a raczej o reakcji łańcuchowej, za pomocą której pewne obszary upodobniły się do siebie kulturowo, ze względu na pozycję, jaką zajmowały w tym cyklu. Istotne znaczenie dla wzajemnych więzi kulturowych pomiędzy wschodnią i środkową Europą a światem egejskim (wschodniośródziemnomorskim) miało nawiązane kontaktów o charakterze handlowym, długo- i krótkofalowym, które w interesującym nas okresie, w znacznej mierze opierały się na brązie i metalurgii tego surowca oraz na bursztynie.

Reasumując, stwierdzimy, że do czynników generujących przemiany kulturowo-społeczne, do których doszło w partii środkowej, wschodniej i południowej Europy w 2. poł. II tysiąclecia p.n.e. możemy zaliczyć relacje o charakterze handlowym/gospodarczym, prawdopodobnie pośrednim, oparte na bursztynie, rudach metali i gotowych wyrobach. W późniejszym czasie natura owych kontaktów uległa zmianie i nabrała bardziej bezpośredniego, militarnego charakteru.

\section{WNIOSKI: MOŻLIWOŚĆ IDENTYFIKACJI LUDÓW MORZA I ICH PÓŁNOCNEJ KOLEBKI}

Szeroki zakres geograficzny i chronologiczny pracy pozwolił na przekrojowe i kompleksowe ukazanie pewnych procesów zachodzących w 2. poł. II tysiąclecia p.n.e. na obszarze środkowej, wschodniej i południowej Europy oraz w pewnym stopniu także 
na Bliskim Wschodzie. Główny temat rozważań stanowią Ludy Morza. Wydarzenia wiązane $\mathrm{z}$ tym sojuszem zostały ukazane $\mathrm{z}$ różnych, niekiedy odmiennym perspektyw. Celem tego zabiegu było zestawienie i porównanie ze sobą europejskich i bliskowschodnich materiałów odnoszących się do najeźdźców.

Najistotniejszy trzon pracy stanowią rozdziały poświęcone analizie źródeł historycznych i archeologicznych, wiązanych z owym ugrupowaniem. Na podstawie epigrafii i ikonografii bardzo ogólnie można określić wygląd poszczególnych ludów, ich uzbrojenie, nazwy plemienne i późniejsze dzieje niektórych z nich. Więcej o pochodzeniu części Ludów Morza mówią centralnoeuropejskie i północnopontyjskie zabytki, jakie na przełomie późnej epoki brązu i wczesnej epoki żelaza pojawiły się w szeroko pojętej strefie egejskiej i na Bliskim Wschodzie. Ich dystrybucja wskazuje na dwutorowy przepływ zachodnimi oraz wschodnimi Bałkanami do strefy egejskiej, następnie na Cypr, skąd ostatecznie trafiały w rejon wschodniego Śródziemnomorza.

Znaleziska wyrobów o korzeniach nadczarnomorskich i transylwańskich, typowych dla kultur Sabatinovka, Noua i Coslogeni, znajdowane w południowej Bułgarii oraz Egei mogą świadczyć o ruchach migracyjnych tych grup w kierunku wschodniego Śródziemnomorza. Ich rozprzestrzenianie objęło rejon Bałkanów, południe kontynentu europejskiego oraz tereny Bliskiego Wschodu. Ponieważ wyroby o takim pochodzeniu wcześniej nie były znane na tym obszarze, zakłada się, że dostały się tam wraz z wędrującymi grupami ludzkimi, częściowo składającymi się na Ludy Morza.

Podobna sytuacja dotyczy artefaktów o genezie środkowoeuropejskiej. Ich obecność w strefie wschodniośródziemnomorskiej jest wiązana z inwazją Ludów Morza. Główny trzon plemion europejskich, tworzących ów konglomerat, miały stanowić grupy kulturowe kręgu kultur pól popielnicowych (KKPP).

Z kolei wyroby o korzeniach bałkańskich i karpackich świadczą o wzajemnych kontaktach kulturowych/handlowych, do jakich dochodziło pomiędzy lokalnymi wspólnotami a mieszkańcami strefy egejskiej. Na mieszany charakter regionalnych kultur składały się impulsy płynące $\mathrm{z}$ terytorium zajmowanego przez społeczności $\mathrm{z}$ ceramiką inkrustowaną oraz z ugrupowań KKPP, jak i z cywilizacji minojskiej/mykeńskiej.

$\mathrm{Na}$ szczególne podkreślenie zasługuje bliższe rozpoznanie roli, jaką w wielorakich kontaktach kulturowych pełniły niektóre obszary leżące na północnej rubieży świata egejskiego. Mam tu na myśli przede wszystkim pewne strategiczne rejony, które doświadczały różnego rodzaju wpływów, zarówno z północy, jak i z południa, co znacznie ułatwiały liczne rzeki (szlaki komunikacyjne/handlowe) przez nie biegnące. Tereny te pełniły różne funkcje: buforowe, jak starożytna Macedonia; kontaktowe, jak rejon Strumy, zachodnia Bułgaria i tranzytowe, jak północno-wschodnie i wschodnie Bałkany.

Szczegółowe analizy wykazały, iż materiały wiązane z Ludami Morza można podzielić na dwa zbiory: (1) śródziemnomorski i (2) w skrócie ujmując „europejski” (w istocie środkowo- i wschodnioeuropejski). Zabytki pierwszej grupy (źródła pisane, ikonograficzne oraz materiał archeologiczny) wykazują brak wzajemnej korelacji, przez co uzupełniają się w nikłym stopniu. Także ich zestawienie nie daje oczekiwanych rezul- 
tatów. Bardziej obiecująco przedstawiają się porównawcze studia pozostałości materialnych, wykazujące nie tylko podobieństwo między zabytkami, ale także świadczące zapewne o fizycznej obecności obcych plemion we wschodniej części Śródziemnomorza. Zabytki tej grupy znajdowane w Grecji i Lewancie świadczą na korzyść europejskich korzeni przynajmniej części plemion Ludów Morza. Schematy ich wędrówek mógł wyglądać następująco: (a) obszar KKPP - Macedonia - Egea (Grecja mykeńska) - Cypr Egipt i Kanaan, gdzie byli znani jako Peleset/Filistyni; (b) północno-zachodni Pont = kompleks kulturowy S-N-C - południowo-wschodnia Bułgaria - Grecja lądowa i Troada - Kreta - Cypr - Egipt i Kanaan, gdzie byli znani jako Szardana. Ponadto nie można wykluczyć, że Tjekker i Tursza pochodzili z Troady, a Lukka z południowo-zachodniej Azji Mniejszej. Lokalizacja pierwotnych siedzib reszty ludów jest dyskusyjna.

\section{„THE SEA PEOPLES” AND CULTURAL TRANSFORMATIONS IN THE PONTIC-BALKAN ZONE IN THE SECOND HALF OF THE SECOND MILLENNIUM BC}

\section{S u m m a ry}

The project intended to investigate cultural, social and political situation of the second half of the second millenium BC in the catchment area of the Black and the Aegean Seas. The cultural transformations taking place at that time in the Pontic-Balkan area have been discussed within this framework. In terms of chronology, it covers the period between 1500 and $1150 \mathrm{BC}$, that is prior to the expansion of the Sea Peoples and shortly afterwards. A particular attention has been drawn on events taking place around the $12^{\text {th }}$ century BC. The primary aim of this work was to specify a nature of interrelations, socio-political structure as well as cultural correlations between Eastern and Southern Europe. These issues were discussed in a broad spatial perspective, partially in reference to temperate Europe, northern Pontic zone, Eastern, Central and Western Balkans and Aegean-Anatolian zone. This allowed for a comprehensive overview of the ,political-historical” situation. The core of the discussion was concentrated on the genesis of the so-called Sea Peoples, whose invasion of the late $13^{\text {th }}$ and $12^{\text {th }}$ centuries BC affected broad areas of the eastern Mediterranean. The study has been based upon the assumption on a possibility of producing a comprehensive overview of archaeological and historical materials making possible to interrogate the Sea Peoples both from the northern (Central and Eastern Europe and the Balkans) and southern perspective (eastern Mediterranean). The most important part of the study has been devoted to detailed analysis of archaeological artefacts and historical documents (written and iconographic sources) making possible to address these issues. Evidence of Sea Peoples invasion from Central and Eastern Europe comprise swords of the Naue II type, swords and daggers of the Krasny Mayak type, spearheads and arrows, a decorative motive of waterfowl heads, hatchets and the so-called barbarian ceramic, among others.

Justyna Cieszewska Muzeum Archeologiczne ul. Wodna 27, 61-731 Poznań, Poland 